\title{
Field Performance of Cut Flower Rose Cultivars in Mississippi
}

\author{
Crofton Sloan ${ }^{1,2}$ and Susan S. Harkness ${ }^{1}$
}

ADDITIONAL INDEX WORDS. Rosa, production, fresh flower

Summary. Rose (Rosa) cultivars from two breeders, Meilland Star and W. Kordes Söhne, were planted in field beds at Verona, Mississippi, to evaluate cut flower production potential. Seventeen cultivars of an outdoor cut flower series of roses from W. Kordes Söhne and nine cultivars of the Romantica series from Meilland Star were planted in adjacent field beds. The number of stems produced per plant and stem length were measured to assess the field production potential of cut flower stems in Mississippi. Based on 2 years of assessment, the best performing W. Kordes Söhne roses were 'Fantasia Mondiale', 'Masquerade', and 'Pinguin', averaging three to 12 stems/plant per month that were at least $30 \mathrm{~cm}$ long, and the best Meilland Star cultivars for outdoor cut flower production were 'Frederic Mistral', 'Michelangelo', 'The McCartney Rose', and 'Traviata', averaging three to $20 \mathrm{stems} /$ plant per month that were at least $30 \mathrm{~cm}$ long. These cultivars performed well during the heat of the Mississippi summer.

$\mathrm{R}$

oses are one of the three main flower crops produced and distributed worldwide, and the large majority of roses purchased in the United States are produced in South America (Armitage, 2000). In 2006, the United States imported cut flowers valued at $\$ 750$ million, while U.S. production of cut flowers was estimated to be valued at $\$ 385$ million (Jerardo, 2006). About one-half of imported flowers are roses (Jerardo, 2006). More cut roses are produced and consumed in the United States than any other flower (Bonarriva, 2003). The majority of cut flower roses are grown in climate-controlled greenhouses where temperature, moisture, and light can be adjusted to produce flowers at periods of peak demand (University of California, 1998). In general, rose cultivars grown in greenhouses are distinct from those grown in landscape plantings.

The value of cut flower production in Mississippi is very small and accounts for $0.2 \%$ of the value of all floriculture and nursery crops grown

Contribution of the Mississippi Agricultural and Forestry Experiments Station journal article no. J-11310.

Mention of trademark or proprietary product does not constitute a guarantee or warranty of the product and does not imply its approval to the exclusion of other products that may also be suitable.

${ }^{1}$ Mississippi State University, North Mississippi Research and Extension Center, P.O. Box 1690, Verona, MS, 38879

${ }^{2}$ Corresponding author. E-mail: rcsloan@ra.msstate. edu. in the state (U.S. Department of Agriculture, 1999). However, a survey of Mississippi consumers reported that they would pay a premium to purchase fresh, cut flowers that were locally produced (Hudson and Griffin, 2004). The survey further indicated that the flowers that Mississippi consumers most often purchased were roses, followed by carnation (Dianthus caryophyllus), iris (Iris), lily (Lilium), and gladiolus (Gladiolus). They also reported that consumers would pay a premium price for flowers with fragrance.

A limited number of research publications evaluating outdoor cut rose cultivars exist. Limited research has been reported on cut flower rose cultivar evaluations in Mississippi. Spencer (1993) evaluated 185 modern rose cultivars in field beds, but these were evaluated for landscape, not cut flower performance. Rose cultivar evaluations for Mississippi do not include cut flower production recommendations (Tatum et al., 1998). The production of two rose cultivars evaluated in southern Alabama greenhouse production trials was reported to be equal to that from other areas of the United States (Cobb, 1983). Tabassum et al. (2002) reported the growth of 10 hybrid tea cultivars, two from W. Kordes Söhne (Klein Offenseth-Sparrieshoop, Germany) and three from Meilland Star (Hollister, CA) grown in field beds in Pakistan. 'Daydream' produced the most stems, whereas 'Double Delight' produced the fewest in this trial. Several specialty cut flower growers have published the results of their efforts to produce fragrant, cut roses for local consumption. W. Kordes Söhne cultivars planted in Idaho (USDA hardiness zone 4) produced numerous short stems in the first production season in field beds (Thurston, 2007). Benzakein (2006) reported that large numbers of stems of W. Kordes Söhne outdoor cut roses were produced in the first growing season in outdoor beds in Washington (USDA hardiness zone 7). This suggests that there are opportunities for locally produced, fragrant roses for local or regional consumption. The objective of this trial was to determine the field production potential of Meilland Star and W. Kordes Söhne cut flower rose cultivars in Mississippi for small-acreage, low-input farmers for local sales. This objective was accomplished by the evaluation of plant growth parameters such as the number of stems produced per plant, stem length, and harvest period of the cultivars. The two series were chosen for this trial because they were promoted as fragrant, cut flower roses for outdoor production.

\section{Materials and methods}

This study was conducted at the North Mississippi Research and Extension Center (NMREC) in Verona (lat. $34.2^{\circ} \mathrm{N}$, long. $88.8^{\circ} \mathrm{W}$ ). Verona is in USDA hardiness zone $7 \mathrm{~b}$ and American Horticulture Society heat zone 8 . Nine Meilland Star

\begin{tabular}{llll}
\hline $\begin{array}{l}\text { Units } \\
\begin{array}{l}\text { To convert U.S. to SI, } \\
\text { multiply by }\end{array}\end{array}$ & U.S unit & SI unit & $\begin{array}{l}\text { To convert SI to U.S., } \\
\text { multiply by }\end{array}$ \\
\hline 0.3048 & $\mathrm{ft}$ & $\mathrm{m}$ & 3.2808 \\
9.3540 & gal/acre & $\mathrm{L} \cdot \mathrm{ha}^{-1}$ & 0.1069 \\
2.54 & inch $(\mathrm{es})$ & $\mathrm{cm}$ & 0.3937 \\
16.3871 & inch & $\mathrm{cm}^{3}$ & 0.0610 \\
1.1209 & $\mathrm{lb} / \mathrm{acre}$ & $\mathrm{kg} \cdot \mathrm{ha}^{-1}$ & 0.8922 \\
$\left({ }^{\circ} \mathrm{F}-32\right) \div 1.8$ & ${ }^{\circ} \mathrm{F}$ & ${ }^{\circ} \mathrm{C}$ & $\left(1.8 \times{ }^{\circ} \mathrm{C}\right)+32$
\end{tabular}


rose cultivars (grade 1) budded onto 'Dr. Huey' (Rosa $\times$ bybrida) rootstock were planted in field beds on a Savannah sandy clay loam soil in Apr. 2005, and 17 W. Kordes Söhne outdoor cut flower rose cultivars (grade 1) were planted in field beds in Dec. 2004. All W. Kordes Söhne rose cultivars were budded onto 'Inermis' ( Rosa canina) rootstock. Field beds, $\approx 8 \mathrm{ft}$ wide, were constructed by mounding soil into a raised bed $\approx 10$ inches higher than the middle between the beds. Composted cattle manure was spread 2 inches deep on top of the beds and then incorporated 4 inches deep. The rose plants were planted $2 \mathrm{ft}$ apart within the row, and the single rows on the top of the beds were spaced $15 \mathrm{ft}$ apart. A single drip tape, placed in the center of the bed on top of the ground, supplied irrigation water. Based on soil test recommendations for rose gardens, beds were fertigated weekly with Peter's 20-2020 (20N-8.8P-16.5K; Scotts, Marysville, $\mathrm{OH}$ ) water-soluble fertilizer at a rate of $24 \mathrm{lb} /$ acre during the growing season. Irrigation was supplied in the absence of rain through 12 -inch spacing drip tape (T-Tape TSX; T-Systems International, San Diego) to provide $125 \mathrm{gal} / 100 \mathrm{ft}$ (linear) of row once per week. Weekly fungicide applications were made to help control foliage diseases. The rose plants were pruned in the dormant season using conventional hybrid tea growing techniques. Pesticides were applied to control weeds, insects, and diseases. Ground pine bark mulch was applied in a 5 - $\mathrm{ft}$ band 2 inches thick.

Experimental units consisted of one plant of each cultivar for the Meilland Star cultivars and two plants of each cultivar that were planted in pairs within the row for the W. Kordes Söhne cultivars. Cultivars of Meilland Star and W. Kordes Söhne were arranged in a randomized complete block design with six and five replications, respectively. Plant size was measured on 9 Feb. 2006 after the growing season. Plant size was measured in cubic centimeters and was calculated using $\pi \cdot \mathrm{r}^{2} \cdot \mathrm{h}$, where $\mathrm{r}^{2}=$ $\{[$ (width $1+$ width 2$) / 2] / 2\}^{2}$. Width 1 was measured across the widest part of the plant and width 2 was measured at a right angle to the first width and $\mathrm{h}=$ plant height. Stem growth, foliage appearance, and overall vigor were components of the growth ratings conducted during the growing season. The ratings ranged from 1 to 5 , where $1=$ poor growth and $5=$ excellent growth. Rose stems were not harvested until Aug. 2005 to grow the framework of the plants. Rose stems were harvested as the petals began to open. Stem length at harvest was determined by cutting to the second or third bud above the point where the stem arose from the parent cane. If stem length was less than $20 \mathrm{~cm}$, the stem was not included in the data set in 2005; in 2006, the minimum stem length for inclusion in the data was $30 \mathrm{~cm}$. The number of stems and stem length data were analyzed monthly to determine cultivar productivity over the length of the harvest season. Data collected during the trial were analyzed by SAS PROC MIXED or PROC GLM (SAS Institute, Cary, NC). Means separations were conducted with Fisher's protected least significant difference at the 0.05 significance level. Because cultivars from the two series were planted at different times in different locations, they were analyzed separately.

\section{Results and discussion}

Meilland star. 'Frederic Mistral' and 'The McCartney Rose' produced larger plants than the other Meilland Star cultivars at the end of the first growing season (Table 1). At the start of the second growing season, 'Frederic Mistral', 'Michelangelo', 'Peter Mayle', and 'The McCartney
Rose' were rated higher for overall plant appearance and landscape appeal than the other cultivars, whereas 'Jean Giono' was rated lower than the other cultivars except 'Guy de Maupassant'.

Rose stems were harvested during August, September, and Oct. 2005. There was an interaction between cultivar and harvest date with respect to the number of stems harvested per plant per month. 'Michelangelo' produced more stems per plant in August compared with the other cultivars in this trial except for 'Guy de Maupassant' and 'Rouge Royale' (Table 2). In September, the stem production of 'Frederic Mistral' was not significantly different from 'Johann Strauss', 'Michelangelo', 'Rouge Royale', and 'Traviata'. In October, stem production for 'Frederic Mistral', 'Guy de Maupassant', 'Johann Strauss', 'Michelangelo', 'The McCartney Rose', and 'Traviata' did not differ, and ranged from 6.6 to 9.2 stems/plant. There was no interaction between cultivar and harvest date with regard to stem length. 'Frederic Mistral', 'The McCartney Rose', and 'Traviata' produced longer stems than the other cultivars in 2005 .

'Frederic Mistral' and 'Michelangelo' produced more stems per plant in May 2006 compared with the other cultivars except 'The McCartney Rose' (Table 3). In June, 'Frederic Mistral' and 'The McCartney Rose' produced more stems than

Table 1. Bloom description, plant size, and plant growth ratings of Meilland Star (Hollister, CA) rose cultivars grown in field beds in 2006 at Verona, MS.

\begin{tabular}{|c|c|c|c|}
\hline Cultivar & $\begin{array}{c}\text { Bloom } \\
\text { description }\end{array}$ & $\begin{array}{c}\text { Plant size in } \\
\text { Feb. } 2006\left(\mathrm{~cm}^{3}\right)^{\mathrm{z}}\end{array}$ & $\begin{array}{c}\text { Plant rating on } \\
27 \text { Apr. } 2006 \\
(1-5 \text { scale })^{y}\end{array}$ \\
\hline Frederic Mistral & Pink & $1,323,614 a^{x}$ & $4.6 \mathrm{a}$ \\
\hline Guy de Maupassant & Pink & $150,070 \mathrm{cde}$ & $3.0 \mathrm{~cd}$ \\
\hline Jean Giono & $\begin{array}{l}\text { Gold, apricot, } \\
\text { yellow }\end{array}$ & 133,459 de & $2.2 \mathrm{~d}$ \\
\hline Johann Strauss & Pink & 204,339 cde & $3.3 \mathrm{bc}$ \\
\hline Michelangelo & Yellow & $472,035 \mathrm{bc}$ & $4.0 \mathrm{ab}$ \\
\hline Peter Mayle & Pink & $202,853 \mathrm{cde}$ & $3.8 \mathrm{a}-\mathrm{c}$ \\
\hline Rouge Royale & Burgundy red & $342,716 \mathrm{cde}$ & $3.5 \mathrm{bc}$ \\
\hline $\begin{array}{l}\text { The McCartney } \\
\text { Rose }\end{array}$ & Pink & $730,948 \mathrm{~b}$ & $4.5 \mathrm{a}$ \\
\hline Traviata & Red & $395,366 \mathrm{~cd}$ & $4.0 \mathrm{ab}$ \\
\hline $\operatorname{LSD}(0.05)^{x}$ & & 323,393 & 0.91 \\
\hline
\end{tabular}

${ }^{\mathrm{z}} 1 \mathrm{~cm}^{3}=0.0610$ inch $^{3}$, plant size $=\pi \cdot \mathrm{r}^{2} \cdot \mathrm{h}$ where $\mathrm{r}^{2}=\{[(\text { width } \mathrm{l}+\text { width } 2) / 2] / 2\}^{2}$ and $\mathrm{h}=$ plant height. ${ }^{\mathrm{y}} 1=$ poor, $5=$ excellent.

${ }^{\mathrm{x}}$ Mean comparison within columns by Fisher's protected least significant difference at $P=0.05$. Means with the same letter do not differ at the $5 \%$ significance level. 
Table 2. Number of stems per plant and stem length of Meilland Star (Hollister, CA) rose cultivars grown in field beds in 2005 at Verona, MS. ${ }^{\mathrm{z}}$

\begin{tabular}{|c|c|c|c|c|}
\hline \multirow[b]{3}{*}{ Cultivar } & \multicolumn{3}{|c|}{ Harvest month } & \multirow[b]{3}{*}{ Stem length $(\mathrm{cm})^{\mathrm{y}}$} \\
\hline & August & September & $\overline{\text { October }}$ & \\
\hline & \multicolumn{3}{|c|}{ Stems (no./plant) } & \\
\hline Frederic Mistral & $2.7 \mathrm{~B} \mathrm{c}^{\mathrm{x}}$ & $6.9 \mathrm{~A} \mathrm{a}$ & $6.9 \mathrm{~A} \mathrm{ab}$ & $38.8 \mathrm{a}$ \\
\hline Guy de Maupassant & $5.2 \mathrm{~A} \mathrm{a}-\mathrm{c}$ & $2.9 \mathrm{Ac}$ & $6.6 \mathrm{~A} \mathrm{ab}$ & $26.8 \mathrm{de}$ \\
\hline Jean Giono & $2.4 \mathrm{Ac}$ & $1.7 \mathrm{Ac}$ & $1.1 \mathrm{Ac}$ & $23.6 \mathrm{e}$ \\
\hline Johann Strauss & $3.8 \mathrm{~B} \mathrm{bc}$ & $4.2 \mathrm{~B} \mathrm{abc}$ & $9.2 \mathrm{~A} \mathrm{a}$ & $25.6 \mathrm{de}$ \\
\hline Michelangelo & $8.1 \mathrm{~A} \mathrm{a}$ & $4.6 \mathrm{~B} \mathrm{a}-\mathrm{c}$ & $8.1 \mathrm{~A} \mathrm{a}$ & \\
\hline Peter Mayle & $2.6 \mathrm{AB} \mathrm{c}$ & $1.7 \mathrm{~B} \mathrm{c}$ & $4.4 \mathrm{~A} \mathrm{~b}$ & $31.0 \mathrm{bc}$ \\
\hline Rouge Royale & $5.8 \mathrm{~A} \mathrm{ab}$ & $6.2 \mathrm{~A} \mathrm{ab}$ & $5.1 \mathrm{~A} \mathrm{~b}$ & $28.4 \mathrm{~cd}$ \\
\hline The McCartney Rose & $2.9 \mathrm{~B} \mathrm{bc}$ & $3.9 \mathrm{~B} \mathrm{bc}$ & $8.6 \mathrm{~A} \mathrm{a}$ & $37.9 \mathrm{a}$ \\
\hline Traviata & $3.5 \mathrm{~B} \mathrm{bc}$ & $4.6 \mathrm{AB}$ abc & $7.1 \mathrm{~A} \mathrm{ab}$ & $37.9 \mathrm{a}$ \\
\hline $\operatorname{LSD}(0.05)^{x}=2.97$ & & & & $\operatorname{LSD}(0.05)=4.04$ \\
\hline \multicolumn{5}{|c|}{$\begin{array}{l}{ }^{2} \text { Because the interaction of cultivar } \times \text { harvest date was significant }(P=0.0018) \text { for the number of stems produced } \\
\text { per plant in } 2005, \text { two comparisons were executed: } 1) \text { within cultivar and across harvest dates, and } 2) \text { within harvest } \\
\text { date and across cultivars. } \\
\text { y } 1 \mathrm{~cm}=0.3937 \text { inch. } \\
{ }^{\mathrm{x}} \text { Mean comparison within columns by Fisher's protected least significant difference at } P=0.05 \text {. Means with the } \\
\text { same lowercase letter in a column do not differ at the } 5 \% \text { significance level. Means with the same uppercase letter in } \\
\text { a row do not differ at the } 5 \% \text { significance level. }\end{array}$} \\
\hline
\end{tabular}

the other cultivars, whereas in July 'The McCartney Rose' produced more stems than the other cultivars, except 'Traviata'. In August, 'Frederic Mistral' produced by far the most stems. 'Guy de Maupassant' and 'Jean Giono' consistently produced fewer stems per plant during the harvest season compared with the other cultivars.

'Peter Mayle' produced longer stems in May 2006 compared with the other cultivars except 'The McCartney Rose' (Table 4). In June, 'Peter Mayle' and 'Traviata' produced longer stems than the other cultivars, except 'Frederic Mistral' and 'The McCartney Rose'. 'Frederic Mistral', 'Michelangelo', 'Peter Mayle', 'The McCartney Rose', and 'Traviata' were in the statistical grouping of cultivars that had the longest stem length in

Table 3. Number of stems per plant for Meilland Star (Hollister, CA) rose cultivars grown in field beds in 2006 at Verona, MS. ${ }^{\mathrm{z}}$

\begin{tabular}{|c|c|c|c|c|c|c|}
\hline \multirow[b]{3}{*}{ Cultivar } & \multicolumn{5}{|c|}{ Stems (no./plant) } & \multirow[b]{3}{*}{$\operatorname{LSD}(\mathbf{0 . 0 5})^{\mathrm{y}}=7.41$} \\
\hline & \multicolumn{5}{|c|}{ Harvest month } & \\
\hline & May & June & July & August & September & \\
\hline Guy de Maupassant & $9.3 \mathrm{Ac}$ & $1.2 \mathrm{~B} \mathrm{~b}$ & $0.5 \mathrm{~B} \mathrm{c}$ & $0.2 \mathrm{~B} \mathrm{~d}$ & $1.2 \mathrm{~B} \mathrm{~b}$ & \\
\hline Jean Giono & $1.5 \mathrm{~A} \mathrm{~d}$ & $0.3 \mathrm{~A} \mathrm{~b}$ & $0.3 \mathrm{~A} \mathrm{c}$ & $0.2 \mathrm{~A} \mathrm{~d}$ & $0.2 \mathrm{~A} \mathrm{~b}$ & \\
\hline Johann Strauss & $10.5 \mathrm{~A} \mathrm{bc}$ & $0.7 \mathrm{~B} \mathrm{~b}$ & $1.5 \mathrm{~B} \mathrm{c}$ & $0.2 \mathrm{~B} \mathrm{~d}$ & $7.5 \mathrm{AB}$ a & \\
\hline Rouge Royale & $6.8 \mathrm{Acd}$ & $2.8 \mathrm{AB} \mathrm{b}$ & $1.5 \mathrm{~B} \mathrm{c}$ & $1.3 \mathrm{~B} \mathrm{~d}$ & $10.0 \mathrm{~A} \mathrm{a}$ & \\
\hline The McCartney Rose & $16.7 \mathrm{~A} \mathrm{ab}$ & $15.2 \mathrm{~A} \mathrm{a}$ & $13.2 \mathrm{~A} \mathrm{a}$ & $10.3 \mathrm{~A} \mathrm{bc}$ & $9.5 \mathrm{~A} \mathrm{a}$ & \\
\hline $\begin{array}{l}\text { Traviata } \\
\end{array}$ & $6.7 \mathrm{~A} \mathrm{~cd}$ & $5.7 \mathrm{~A} \mathrm{~b}$ & $9.7 \mathrm{~A} \mathrm{ab}$ & $11.2 \mathrm{~A} \mathrm{~b}$ & $6.7 \mathrm{~A} a \mathrm{~b}$ & \\
\hline
\end{tabular}

$\operatorname{LSD}(0.05)=7.09$

${ }^{2}$ Because the interaction of cultivar $\times$ harvest date was significant $(P<0.0001)$ for the number of stems produced per plant in 2006 , two comparisons were executed: 1$)$ within cultivar and across harvest dates, and 2 ) within harvest date and across cultivars.

'Mean comparison within columns by Fisher's protected least significant difference at $P=0.05$. Means with the same lowercase letter in a column do not differ at the $5 \%$ significance level. Means with the same uppercase letter in a row do not differ at the $5 \%$ significance level.

Table 4. Stem length of Meilland Star (Hollister, CA) rose cultivars grown in field beds in 2006 at Verona, MS. ${ }^{\mathrm{z}}$

\begin{tabular}{|c|c|c|c|c|c|c|}
\hline \multirow[b]{3}{*}{ Cultivar } & \multicolumn{5}{|c|}{ Stem length $(\mathrm{cm})^{\mathrm{y}}$} & \multirow[b]{3}{*}{$\operatorname{LSD}(0.05)^{x}=4.59$} \\
\hline & \multicolumn{5}{|c|}{ Harvest month } & \\
\hline & May & June & July & August & September & \\
\hline Guy de Maupassant & $32.2 \mathrm{~A} \mathrm{~cd}$ & $32.8 \mathrm{~A} \mathrm{bcd}$ & $33.8 \mathrm{~A} \mathrm{abc}$ & $29.9 \mathrm{~A} \mathrm{c}$ & $31.0 \mathrm{~A} \mathrm{~cd}$ & \\
\hline Jean Giono & $30.4 \mathrm{AB} \mathrm{d}$ & $31.0 \mathrm{AB} \mathrm{d}$ & $34.9 \mathrm{~A} \mathrm{ab}$ & $29.7 \mathrm{~B} \mathrm{c}$ & $29.3 \mathrm{~B} \mathrm{~d}$ & \\
\hline Johann Strauss & $31.2 \mathrm{~A} \mathrm{~cd}$ & $30.7 \mathrm{~A} \mathrm{~d}$ & $30.7 \mathrm{~A} \mathrm{bc}$ & $29.7 \mathrm{~A} \mathrm{c}$ & $31.0 \mathrm{~A} \mathrm{~cd}$ & \\
\hline Rouge Royale & $32.2 \mathrm{AB} \mathrm{cd}$ & $33.2 \mathrm{AB}$ bcd & $29.9 \mathrm{~B} \mathrm{c}$ & $30.4 \mathrm{~B} \mathrm{bc}$ & $35.0 \mathrm{~A} \mathrm{bc}$ & \\
\hline The McCartney Rose & $37.3 \mathrm{~A} \mathrm{ab}$ & $36.3 \mathrm{~A} \mathrm{a}-\mathrm{c}$ & $35.9 \mathrm{~A} \mathrm{a}$ & $34.3 \mathrm{~A} \mathrm{ab}$ & $36.7 \mathrm{~A} \mathrm{ab}$ & \\
\hline Traviata & $31.8 \mathrm{~B} \mathrm{~cd}$ & $38.5 \mathrm{~A} \mathrm{a}$ & $34.9 \mathrm{AB} \mathrm{ab}$ & $37.0 \mathrm{~A} \mathrm{a}$ & $35.7 \mathrm{AB} b$ & \\
\hline $\operatorname{LSD}(0.05)=4.46$ & & & & & & \\
\hline
\end{tabular}


July and August. In September, 'Frederic Mistral' produced longer stems than the other cultivars except 'The McCartney Rose'. 'Frederic Mistral' and 'The McCartney Rose' produced vigorous, healthy bushes and large number of long stems throughout the 2006 growing season.

W. Kordes SöHNe. Plant vigor and growth of W. Kordes Söhne cultivars were rated 25 May 2005.
'Fantasia Mondiale' and 'Pinguin' had the highest vigor ratings of all cultivars in May 2005 except for 'Caramel Antike', 'Red Queen', and 'Taifun' (Table 5). Growth ratings taken in Apr. 2006 showed that 'Fantasia Mondiale' and 'Pinguin' were the highest rated cultivars. 'Eliza' was the second highest rated cultivar in 2006, but did not differ from 'Red Queen' and 'Masquerade'. Plant size was measured after the 2005 growing season, and 'Masquerade' and 'Fantasia Mondiale' were larger after the first growing season than the other cultivars in the trial. 'Pinguin' was smaller than 'Masquerade' and 'Fantasia Mondiale', but was larger than the other cultivars in the trial except 'Eliza'.

Rose stems were harvested during August, September, and Oct.

Table 5. Bloom description, plant size, and plant growth ratings of W. Kordes Söhne (Klein Offenseth-Sparrieshoop, Germany) rose cultivars grown in field beds in 2005 and 2006 at Verona, MS.

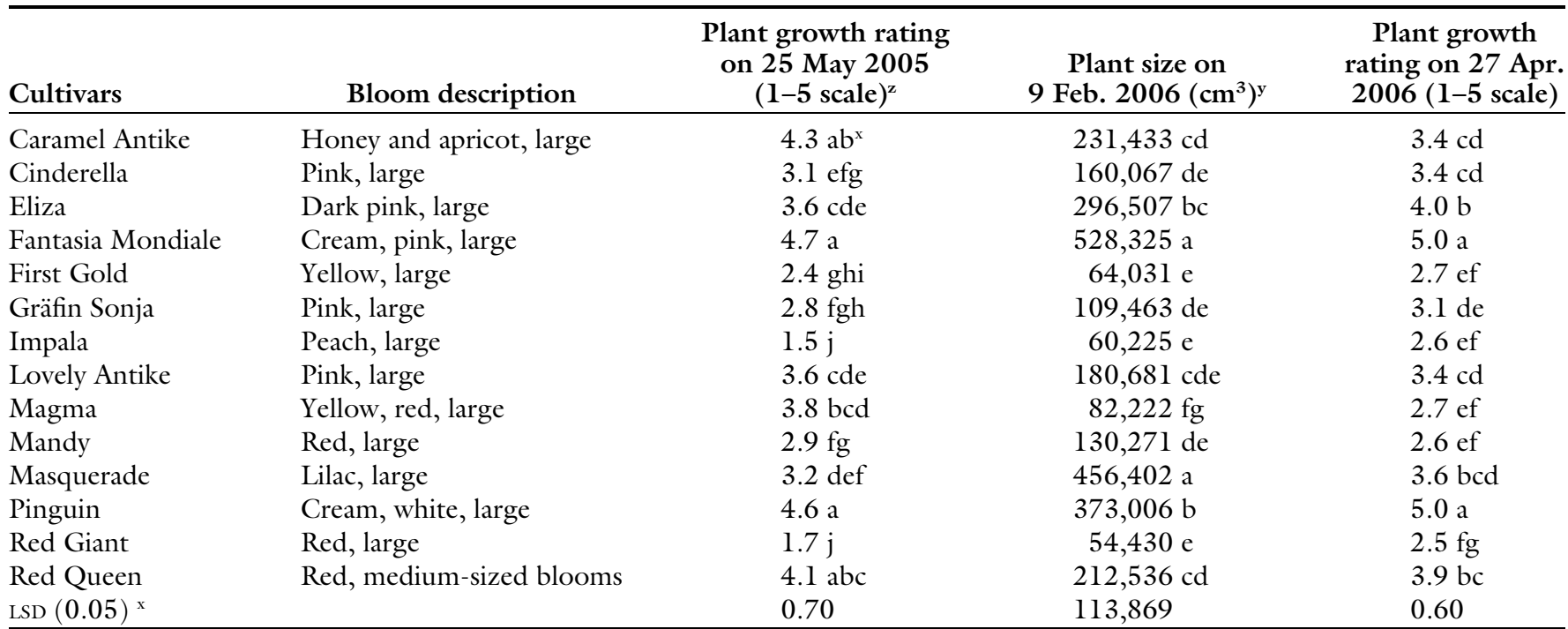

${ }^{\mathrm{z}} \mathrm{l}=$ poor, 5 = excellent.

${ }^{\mathrm{y}} 1 \mathrm{~cm}^{3}=0.0610$ inch $^{3}$, plant size $=\pi \cdot \mathrm{r}^{2} \cdot \mathrm{h}$ where $\mathrm{r}^{2}=\{[$ (width $\mathrm{l}+$ width 2$\left.) / 2] / 2\right\}^{2}$ and $\mathrm{h}=$ plant height.

${ }^{x}$ Mean comparison within columns by Fisher's protected least significant difference at $P=0.05$. Means with the same letter do not differ at the $5 \%$ significance level.

Table 6. Number of stems per plant and stem length of W. Kordes Söhne (Klein Offenseth-Sparrieshoop, Germany) rose cultivars grown in field beds in 2005 at Verona, MS. ${ }^{\mathrm{z}}$

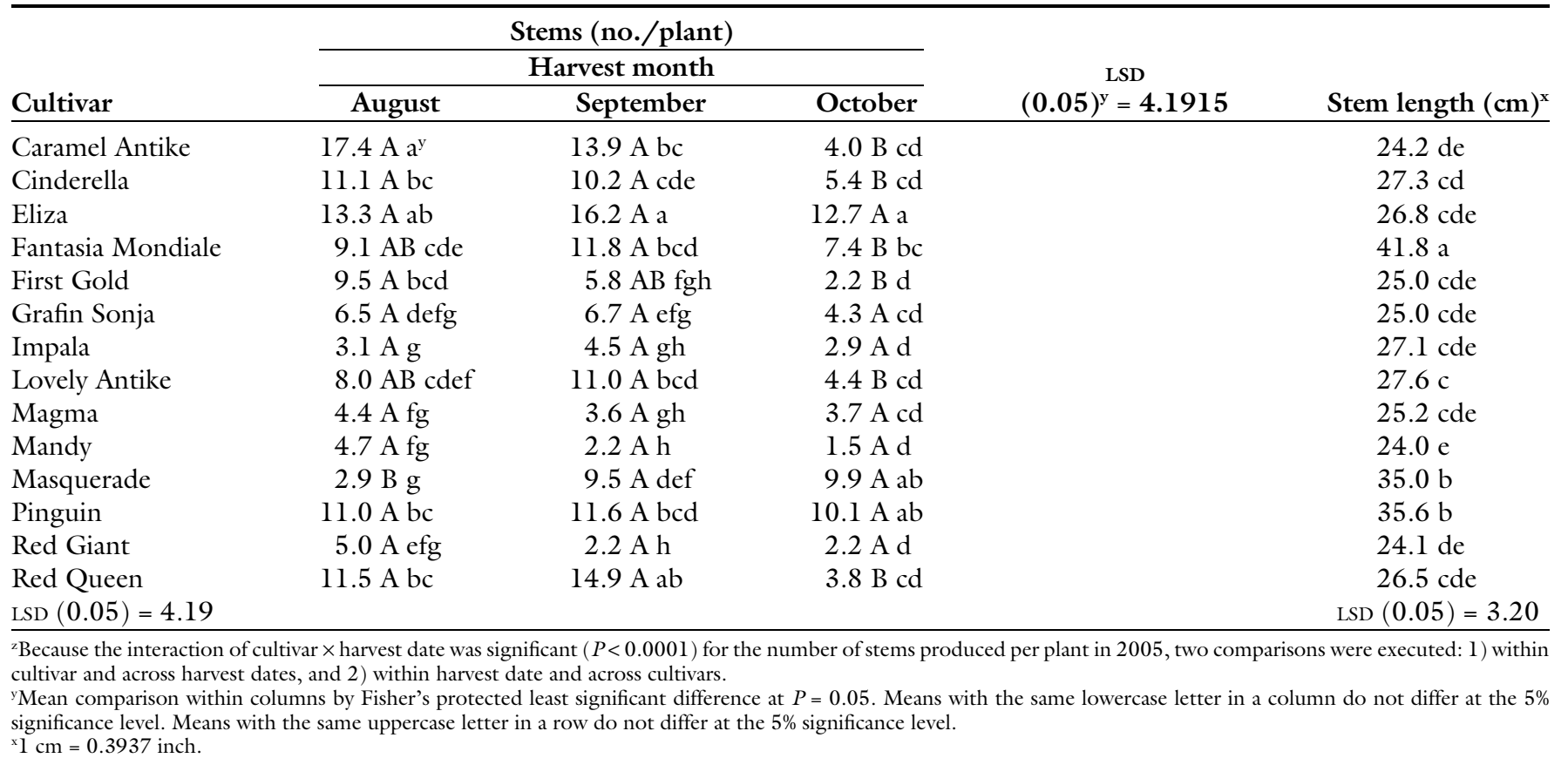


Table 7. Number of stems per plant per mo. (May-October) and stem length of W. Kordes Söhne (Klein Offenseth-Sparrieshoop, Germany) rose cultivars grown in field beds in 2006 at Verona, MS.

\begin{tabular}{lcc}
\hline Cultivar & $\begin{array}{c}\text { Stems } \\
\text { (no./plant per mo.) }\end{array}$ & $\begin{array}{c}\text { Stem length } \\
(\mathbf{c m})^{\mathbf{z}}\end{array}$ \\
\hline Caramel Antike & $1.57 \mathrm{~cd}^{\mathrm{y}}$ & $31.34 \mathrm{~cd}$ \\
Cinderella & $1.42 \mathrm{~cd}$ & $32.47 \mathrm{~cd}$ \\
Eliza & $3.06 \mathrm{bcd}$ & $32.99 \mathrm{~cd}$ \\
Fantasia Mondiale & $7.79 \mathrm{a}$ & $37.12 \mathrm{~b}$ \\
First Gold & $0.79 \mathrm{~d}$ & $31.08 \mathrm{~cd}$ \\
Grafin Sonja & $0.49 \mathrm{~d}$ & $32.31 \mathrm{~cd}$ \\
Impala & $0.64 \mathrm{~d}$ & $31.63 \mathrm{~cd}$ \\
Lovely Antike & $0.69 \mathrm{~d}$ & $30.88 \mathrm{~cd}$ \\
Magma & $0.73 \mathrm{~d}$ & $31.61 \mathrm{~cd}$ \\
Mandy & $0.53 \mathrm{~d}$ & $30.72 \mathrm{~d}$ \\
Masquerade & $4.14 \mathrm{bc}$ & $36.46 \mathrm{~b}$ \\
Pinguin & $5.64 \mathrm{ab}$ & $40.07 \mathrm{a}$ \\
Red Giant & $0.83 \mathrm{~d}$ & $31.52 \mathrm{~cd}$ \\
Red Queen & $1.73 \mathrm{~cd}$ & $33.19 \mathrm{c}$ \\
LSD $(0.05)^{\mathrm{y}}$ & 2.74 & 2.39 \\
\hline
\end{tabular}

${ }^{\mathrm{z}} 1 \mathrm{~cm}=0.3937$ inch.

yean comparison within columns by Fisher's protected least significant difference at $P=0.05$. Means with the same letter do not differ at the $5 \%$ significance level.

2005. There was an interaction between cultivar and harvest date with respect to the number of stems harvested per plant per month. 'Caramel Antike' produced more stems per plant than the other cultivars except 'Eliza' in August (Table 6). In September, 'Eliza' produced more stems per plant than the other cultivars except 'Red Queen'. In October, 'Eliza' produced more stems than the other cultivars except 'Pinguin' and 'Masquerade'. 'Fantasia Mondiale' produced the longest stems in the trial, and the stems of 'Masquerade' and 'Pinguin' were longer than the other cultivars. There was very little difference in stem length among the other cultivars. There were many short stems on most cultivars, but the stems were not measured if they were less than $20 \mathrm{~cm}$ long.

The first stems of 2006 were harvested in April. Stems less than $30 \mathrm{~cm}$ long were not measured. 'Fantasia Mondiale' produced more stems per plant than the other cultivars in the trial except 'Pinguin' (Table 7). Statistically, 'Eliza' and 'Masquerade' yielded the same number of stems as 'Pinguin'. 'Pinguin', 'Fantasia Mondiale', and 'Masquerade' produced the longest stems of the trial, at 40.1 to $36.5 \mathrm{~cm}$.

The objective of this research was to evaluate the field production potential of new cut flower rose cultivars in Mississippi where growers of flowers for local sales may not have climate-controlled greenhouses for rose production. There are no reports of previous evaluations of these cultivars in field beds. The W. Kordes Söhne cultivars were planted in this trial before they were released for sale in the United States. The optimum temperature for rose stem production is around $25^{\circ} \mathrm{C}$, and a $40 \%$ reduction in photosynthesis of cut flower rose plants was observed when the temperature increased from $25{ }^{\circ} \mathrm{C}$ to $40{ }^{\circ} \mathrm{C}$ (Jiao and Grodzinski, 1998). The average high-low (day-night) temperatures at NMREC in JuneSept. 2005 and 2006 were well above the optimum reported temperatures for cut rose production (Mississippi State University Extension Service, 2008). The shoot length of miniature roses grown in a growth chamber decreased $31 \%$ when the high-low temperatures were raised from $21 / 16{ }^{\circ} \mathrm{C}$ to $30 /$ $21{ }^{\circ} \mathrm{C}$ (day/night) (Grossi and Pemberton, 2004). Hybrid tea roses in Mississippi landscapes typically have a spring and autumn flush of bloom with a reduction in bloom during the heat of the summer. Several of the Meilland Star and W. Kordes Söhne cultivars in this evaluation consistently produced a greater number of longer stems from the spring, summer, and autumn growing conditions in this experiment. The number of stems and stem length data indicate that 'Frederic Mistral',
'Michelangelo', and 'The McCartney Rose' of the Meilland Star cultivars, and 'Fantasia Mondiale', 'Masquerade', and 'Pinguin' from the W. Kordes Söhne outdoor cut flower cultivars performed the best in the harsh summer environment of the NMREC in 2005 and 2006.

This study evaluated the performance of cut flower rose cultivars bred for outdoor production of florist flowers. During two summer growing seasons, 'Frederic Mistral', 'Michelangelo', and 'The McCartney Rose' of the Meilland Star cultivars, and 'Fantasia Mondiale', 'Masquerade', and 'Pinguin' from the W. Kordes Söhne outdoor cut flower cultivars produced the greatest number and the longest cut flower stems. These cultivars performed well through the heat of the Gulf of Mexico coastal summer.

\section{Literature cited}

Armitage, A.M. 2000. Specialty cut flowers. The production of annuals, perennials, bulbs, and woody plants for fresh and dried cut flowers. Varsity Press/Timber Press, Portland, OR.

Benzakein, E. 2006. American beauty rose. Cut Flower Quarterly 18(4):33-34.

Bonarriva, J. 2003. Industry \& trade summary: Cut flowers. U.S. Intl. Trade Commission. Publ. 3580.

Cobb, G.S. 1983. Preliminary evaluation of cut rose production in south Alabama. Alabama Agr. Expt. Sta. Res. Rpt. 1(Ornamentals): 11 .

Grossi, J.A.S. and H.B. Pemberton. 2004. Influence of cultivar and seasonal growing environment on growth and postharvest characteristics of single-shoot pot rose plants. HortScience 39:138-141.

Hudson, D. and E. Griffin. 2004. Market potential for "Mississippi grown" cut flowers. Mississippi Agr. For. Expt. Sta. Bul. 1140.

Jerardo, A. 2006. Floriculture and nursery crops outlook. U.S. Dept. Agr., Econ. Res. Serv. FLO-05.

Jiao, J. and B. Grodzinski. 1998. Environmental influences on photosynthesis and carbon export in greenhouse roses during development of the flower shoot. J. Amer. Soc. Hort. Sci. 123:1081-1088.

Mississippi State University Extension Service. 2008. Delta Res. Ext. Ctr. historic ag weather data. 28 Feb. 2008. <http:// ext.msstate.edu/anr/drec/stations.cgi>. 
Spencer, J.A. 1993. Evaluation of the performance of heritage and modern roses. Mississippi Agr. For. Expt. Sta. Bul. 999.

Tabassum, R., A. Ghaffoor, K. Waseem, and M.A. Nadeem. 2002. Evaluation of rose cultivars as cut flower production. Asian J. Plant Sci. 1(6):668-669.
Tatum, D., J.A. Spencer, and M.V. Patel. 1998. Roses in Mississippi. Mississippi State Univ. Ext. Serv. Publ. 529.

Thurston, R. 2007. Growing and marketing specialty cut (fragrant) roses in a northern climate. Cut Flower Quarterly 19(2):11, 37-38.
University of California. 1998. California cut roses: Production and preservation: Part 1. Growing Points 2(3):1.

U.S. Department of Agriculture. 1999. Floriculture and environmental horticulture situation and outlook report. U.S. Dept. Agr., Econ. Res. Serv., Market Trade Econ. Div. October 1999. FLO-1999. 